\title{
PENGARUH METODE PEMBELAJARAN INKUIRI DAN DISKUSI PADA MATERI POKOK BENTUK ALJABAR TERHADAP KEAMPUAN KOMUNIKASI DAN KEMAMPUAN PEMECAHAN MASALAH MATEMATIKA
}

\author{
Ali Sadikin Wear ${ }^{*}$, Renny Indrawati ${ }^{2}$ \\ ${ }^{1}$ Politeknik Perikanan Negeri Tual, ${ }^{2}$ SDN Palmerah 19 Pagi
}

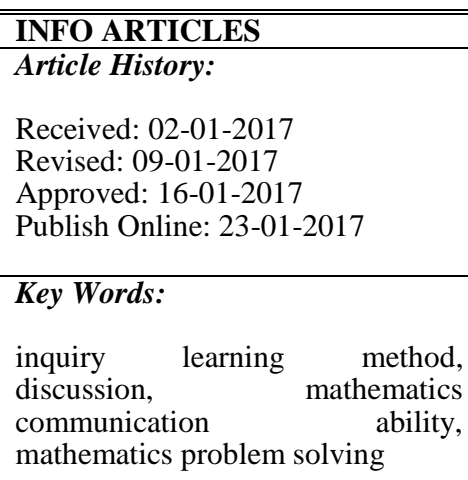

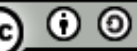

This article is licensed under a Creative Commons AttributionShareAlike 4.0 International License.

\begin{abstract}
The research is aimed to know; 1) interaction of inquiry learning method application and discussion on communication ability and student's mathematics problem solving skills on multivariate. 2) the impacts of learning method on mathematics communication ability on univariat.3) the impacts of learning method on mathematics problem solving skills on univariat. This research is false experiment used non equivalent control group design with 2 factors measurement technique. The instrument is essay test (problem solving and communication question). This research was conducted at public SMP in Palmerah distric, west Jakarta. The sample is the students of class VIII about 140 students. Data analyze used MANOVA analysis. The result of this research is: 1) there are significant impacts of learning method on communication ability and mathematics problem solving skills on multivariate. 2) there are significant impacts of learning method on mathematics communication ability on univariat 3) there isn't significant impact of learning method on mathematics problem solving skills.
\end{abstract}

\begin{abstract}
Abstrak: Penelitian ini bertujuan untuk mengetahui: (1) Interaksi antara penerapan metode pembelajaran inkuiri dan diskuisi terhadap peningkatan kemampuan komunikasi dan pemecahan masalah matematia siswa secara multivariat; (2) pengaruh metode pembelajaran terhadap kemampuan komunikasi matematika secara univariat; (3) pengaruhmetode pembelajaran terhadap kemampuan pemecahan masalah matematika secara univariat. Penelitian ini merupakan penelitian eksperimen semu dengan desain nonequivalent control group dengan pengukuran teknik dua faktor dan instrument yang digunakan adalah tes uraian (soal pemecahan masalah dan komunikasi. Penelitian ini dilakukan di SMP Negeri di Kecamatan Palmerah Jakarta Barat, sedangkan yang menjadi sampelnya adalah siswa kelas VIII sebanyak 140 orang. Analisis data menggunakan teknik analisis MANOVA. Hasil penelitian ini yaitu: 1) terdapat pengaruh yang signifikan metode pembelajaran terhadap kemampuan komunikasi dan pemecahan masalah matematika secara multivariat; 2) terdapat pengaruh yang signifikan metode pembelajaran terhadap kemampuan komunikasi matematika secara univariat; 3) terdapat pengaruh yang tidak signifikan metode pembelajaran terhadap kemampuan pemecahan masalah matematika secara univariat.
\end{abstract}

\footnotetext{
Correspondence Address: Jln. Sathean KM 6, Kecamatan Kei Kecil - Maluku Tenggara, Indonesia; e-mail: alisadikinwear@gmail.com

How to Cite (APA $6^{\text {th }}$ Style): Wear, AS. Indrawati, R. (2017). Pengaruh Metode Pembelajaran Inkuiri Dan Diskusi Pada Materi Pokok Bentuk Aljabar Terhadap Keampuan Komunikasi Dan Kemampuan Pemecahan Masalah Matematika. JKPM (Jurnal Kajian Pendidikan Matematika), 02 (02), 159-172.

Copyright: Wears, A.S. dan Indrawati, R, (2017)

Competing Interests Disclosures: The authors declare that they have no significant competing financial, professional or personal interests that might have influenced the performance or presentation of the work described in this manuscript.
} 


\section{PENDAHULUAN}

Dalam dunia pendidikan, proses belajar mengajar bukan sekedar kegiatan menyampaikan pengetahuan dari guru kepada siswa, akan tetapi lebih dari itu yaitu adanya kegiatan atau proses komunikasi dan informasi dari guru kepada siswa, atau dari siswa kepada guru, dan dari siswa kepada siswa lainnya.

Bagi seorang guru, bahwa di dalam proses pembelajaran seyogyanya kita memperhatikan pengalaman seperti apa yang ingin diharapkan didapat oleh siswa dari proses belajar mengajar itu. Tujuan yang ingin dicapai dalam pendidikan tentunya dilakukan melalui proses komunikasi. Komunikasi dalam pendidikan merupakan faktor yang menjadi inti pembicaraan guru dan siswa dalam mentransfer pengetahuan yang dilakukan secara verbal. Komunikasi secara verbal bersifat instruksional yang berarti bukan suatu perintah melainkan suatu pengajaran dalam sebuah proses pembelajaran di sekolah. Belajar merupakan proses yang dilakukan seseorang untuk mendapatkan pengetahuan, pengalaman dalam suatu kebiasaan yang relatif permananen akan perubahan tingkah laku sebagai hasil interaksi dengan lingkungannya. Belajar matematika merupakan suatu proses pembentukan pola pikir yang mengkoordinasikan konstruk-konstruk logika yang secara verbal berupa bahasa simbol. Bahasa matematika berupa simbol merupakan media komunikasi antara guru (sebagai komunikator) dan siswa (sebagai komunikan) dengan topik pembicaraannya adalah aljabar, geometri dan analisis.

NCTM (National Council of Teachers of Mathematics) merekomendasikan 4(empat) prinsip pembelajaran matematika, yaitu : a) Matematika sebagai pemecahan masalah: b) Matematika sebagai penalaran; c) Matematika sebagai komunikasi, dan; d) Matematika sebagai hubungan (Suherman, 2003:298). Matematika perlu diberikan kepada siswa untuk membekali mereka dengan kemampuan berpikir logis, analitis, sistematis, kritis, dan kreatif serta kemampuan bekerjasama. Standar Isi dan Standar Kompetensi Lulusan (Depdiknas, 2006:346) menyebutkan pemberian mata pelajaran matematika bertujuan agar peserta didik memiliki kemampuan sebagai berikut. a) Memahami konsep matematika, menjelaskan keterkaitan antara konsep dan mengaplikasi konsep atau logaritma secara luwes, akurat, efisien dan tepat dalam pemecahan masalah; b) Menggunakan penalaran pada pola dan sifat, melakukan manipulasi matematika dalam membuat generalisasi, menyusun bukti, atau menjelaskan gagasan dan pernyataan matematika; c) Memecahkan masalah yang meliputi kemampuan memahami masalah, merancang model matematika, menyelesaikan model, dan menafsirkan solusi yang diperoleh; d) Mengkomunikasikan gagasan dengan simbol, tabel, diagram, atau media lain untuk menjelaskan keadaan/masalah; e) Memiliki sifat menghargai kegunaan matematika dalam kehidupan, yaitu: memiliki rasa ingin tahu, perhatian, dan minat dalam pelajaran matematika serta sikap ulet dan percaya diri dalam pemecahan masalah.

Tujuan umum pertama, pembelajaran matematika pada jenjang pendidikan dasar dan menengah adalah memberikan penekanan pada penataan latar dan pembentukan sikap siswa. Tujuan umum adalah memberikan penekanan pada keterampilan dalam penerapan matematika, baik dalam kehidupan sehari-hari maupun dalam membantu mempelajari ilmu pengetahuan lainnya. Fungsi mata pelajaran matematika sebagai: alat, pola pikir, dan ilmu. Pembelajaran matematika di sekolah menjadikan guru sadar akan perannya sebagai motivator dan pembimbing siswa dalam pembelajaran matematika di sekolah. Peran guru inilah yang merupakan salah satu motivasi eksternal kepada siswa dan menstimulus motivasi yang akan muncul dalam diri siswa itu sendiri.

Dengan demikian dalam pembelajaran matematika, komunikasi sangat diperlukan dalam membantu siswa mengasah kemampuan berkomunikasi, menyampaikan dan mengekspresikan ideide matematikanya. Dalam pembelajaran dikenal tiga bentuk komunikasi, yaitu komunikasi linier atau satu arah, komunikasi relasional atau interkasi dan komunikasi konvergen atau multi arah, sedangkan dalam proses pembelajaran matematika dikenal dengan komunikasi konvergen atau multi arah dimana terjadi diantara penerima pesan menuju satu fokus atau minat yang dipahami bersama 
yang berlansgung secara dinamis dan perkembang ke arah pemahaman kolektif dan berkesinambungan.

Istilah komunikasi atau dalam bahasa Inggris communication berasal dari kata Latin communicatio, dan bersumber dari kata communis yang berarti sama (Wardani, 2005:81). Komunikasi adalah istilah yang sering didengar dalam kehidupan sehari-hari. Komunikasi merupakan suatu hubungan, dimana dalam berkomunikasi tersirat adanya interaksi. Interaksi tersebut terjadi karena ada sesuatu yang dapat berupa informasi atau pesan yang ingin disampaikan. Komunikasi merupakan cara berbagi gagasan dan mengklasifikasikan pemahaman. Melalui komunikasi, gagasan menjadi objek-objek refleksi, penghalusan, diskusi, dan perombakan. Komunikasi merupakan suatu proses yang melibatkan dua orang atau lebih, dan di dalamnya terjadi pertukaran informasi dalam rangka mencapai suatu tujuan tertentu. Menurut Hardjana (Naim, 2011) komunikasi merupakan proses penyampaian makna dalam bentuk ide atau informasi yang berasal dari seseorang kepada orang lain melalui media tertentu. Pertukaran makna merupakan inti dari kegiatan komunikasi. Karena dalam komunikasi yang terpenting bukan kata-kata, melainkan makna dari kata-kata. Dalam komunikasi baik pengirim maupun penerima terus- menerus saling memberi dan menerima baik pengaruh maupun dampak dari komunikasi tersebut. Matematika adalah ilmu tentang bilangan-bilangan, hubungan antara bilangan, dan prosedur operasional yang digunakan dalam penyelesaian masalah mengenai bilangan (Depdikbud, 2008:637). Matematika merupakan bentuk komunikasi yang hampir mendekati kesempurnaan dari segenap bentuk komunikasi yang ada. Karena matematika merupakan bahasa yang melambangkan serangkaian makna dari pernyataan yang ingin disampaikan. Tanpa itu maka matematika hanya merupakan kumpulan rumus-rumus yang mati (Jujun, 2007:190). Komunikasi matematis dapat diartikan sebagai cara siswa dalam menyampaikan sesuatu yang diketahuinya melalui peristiwa dialog atau saling hubungan yang terjadi di lingkungan kelas, dimana terjadi pengalihan pesan. Pesan yang dialihkan berisi tentang materi matematika yang dipelajari siswa misalnya berupa konsep, rumus, atau strategi penyelesaian suatu masalah. Pihak yang terlibat dalam peristiwa komunikasi di dalam kelas adalah guru dan siswa. Cara pengalihan pesannya dapat secara lisan maupun tertulis. Secara garis bessar kemampuan komunikasi matematika siswa adalah: 1) menulis tentang matematika (menuliskan apa yang diketahui dan yang ditanyakan); 2) membuat pemodelan $m$

atematika; 3) menjelaskan ide, situasi, atau relasi, matematika dengan gambar atau aljabar; 4) menghubungkan gambar ke dalam ide matematika; dan 5) keruntutan jawaban.

Disampig itu dalam belajar matematika, unsur comprehension/pemahaman tidak dapat dipisahkan dari unsur-unsur psikologis yang lain, dengan menstimulus motivasi menumbuhkan konsentrasi dan reaksi dari pembelajar yang dapat mengembangkan fakta-fakta, ide-ide atau skill. Comprehension/pemahaman dalam belajar tidak hanya sekedar tahu, tetapi juga menghendaki agar subjek belajar dapat memanfaatkan bahan-bahan yang telah dipahami. Namun kenyataannya banyak sekali pembelajar yang melupakan unsur comprehension/pemahaman dalam belajar, banyak diantara mereka belajar hanya dilakukan pada malam hari saat menjelang ujian. Kegiatan belajar seperti inilah yang memiliki kecenderungan bahwa belajar melalui comprehension/pemahaman hanya sekedar mengetahui sesuatu bahan yang dituangkan pada kertas ujian.

Untuk mencapai tingkat pemahaman siswa maka dalam proses pembelajaran diperlukan pengelompokan siswa dalam pemecahan masalah matematika dalam meningkatkan pemahaman terhadap matematika. Adanya pembagian kelompok siswa dalam pembelajaran dengan kemampuan awal yang heterogen, akan mendorong terjalinnya hubungan yang saling mendukung antar anggota kelompok. Siswa yang mengalami kesulitan dapat bertanya baik kepada siswa lain maupun kepada guru, sehingga diharapkan akan dapat meningkatkan kemampuan pemecahan masalah siswa dan hasil belajar yang diperoleh bisa lebih maksimal. Pada awal proses pembelajaran siswa yang berpengetahuan rendah mungkin mengalami kesulitan dalam beradaptasi, karena mereka dituntut dapat memecahkan permasalahan yang ada secara mandiri, namun secara bertahap mereka dapat menyesuaikan dengan proses pembelajaran yang ada. Hal ini disebabkan sudah terjalin hubungan yang saling mendukung antar anggota kelompok, untuk bersama-sama memperoleh hasil belajar yang maksimal. Siswa yang lebih pandai 
membantu siswa yang kurang pandai, sehingga siswa yang berkemampuan kurang memiliki guru yang berasal dari teman kelompoknya. Dengan demikian terjadi proses pengajaran oleh rekan sebaya (peer teaching). Hal ini sesuai dengan pendapat Lie (2002: 43) yang menyatakan bahwa kelompok heterogen memberi kesempatan untuk saling mengajar (peer tutoring) dan saling mendukung.

Dalam hal ini masalah didefinisikan sebagai suatu persoalan yang tidak rutin, belum dikenal cara penyelesaiannya. Justru pemecahan masalah adalah mencari atau menemukan cara penyelesaian (menemukan pola, aturan, .atau algoritma). Sintaknya adalah: sajikan permasalahan yang memenuhi kriteria di atas, siswa berkelompok atau individual mengidentifikasi pola atau aturan yang disajikan, siswa mengidentifkasi, mengeksplorasi, menginvestigasi, menduga, dan akhirnya menemukan solusi.Pemecahan masalah pada dasarnya adalah belajar menggunakan metode-metode ilmiah atau berpikir secara sistematis, logis, teratur, dan teliti. Tujuannya adalah untuk memperoleh kemampuan dan kecakapan kognitif.

Pemecahan masalah diterjemahkan dari "problem solving”. Menurut Gagne pemecahan masalah adalah tipe belajar yang tingkatknya paling kompleks dibandingkan dengan tipe belajar lainnya1. Menurut Conney dalam Risnawati (2008:83) mengajarkan masalah kepada siswa, memungkinkan siswa itu lebih analitik dalam mengambil keputusan dalam hidupnya. Salah satu fungsi utama pembelajaran matmatika adalah untuk mengembangkan kemampuan pemecahan masalah menurut Gagne yang dikutip oleh Wena (2009:52) sebagai berikut, Pemecahan masalah dipandang sebagai suatu proses untuk menemukan kombinasi dari sejumlah aturan yang dapat diterapkan dalam upaya mengatasi situasi baru. Pemecahan masalah tidak sekadar bentuk kemampuan menerapkan aturan-aturan yang telah dikuasai melalui kegiatan-kegiatan belajar terdahulu, tetapi juga merupakan proses untuk mendapatkan seperangkat aturan pada tingkat yang lebih tinggi. Apabila seseorang telah mendapatkan suatu kombinasi perangkat aturan yang dapat dioperasikan sesuai dengan situasi yang sedang dihadapi, maka berarti ia sudah dapat memecahkan suatu masalah.

Masalah merupakan sesuatu yang memerlukan penyelesaian ataupun persoalan yang memerlukan jawaban. Hudojo (1990:167) dalam bukunya menyatakan bahwa "suatu pertanyaan atau soal merupakan suatu masalah apabila pertanyaan tersebut menantang untuk dijawab yang jawabannya tidak dapat dilakukan secara rutin saja". Menyelesaikan masalah, orang harus menguasai hal-hal yang telah dipelajari sebelumnya dan kemudian menggunakannya dalam situasi baru. Karena itu, masalah yang disajikan kepada siswa harus sesuai dengan kemampuan dan kesiapannya serta proses penyelesaiannya tidak dapat dengan prosedur rutin. Cara melaksanakan kegiatan mengajar, siswa diberi pertanyaan-pertanyaan dari yang mudah ke yang sulit secara hirarkis. Kemampuan pemecahan masalah matematika siswa ditekankan pada berfikir tentang cara memecahkan masalah dan memproses informasi matematika. Polya sebagaimana yang dikutip Zakaria (2007:143) mengatakan bahwa terdapat empat prosedur dalam pemecahan masalah matematika, yaitu: a) memahami masalah; b) merencanakan pemecahan masalah; c) melaksanakan pemecahan masalah; d) memeriksa kembali.

Masalah dalam matematika merupakan suatu persoalan yang siswa sendiri seharusnya mampu menyelesaikan tanpa menggunakan cara yang rutin. Pemecahan masalah dalam matematika adalah proses menemukan jawaban dari suatu pertanyaan yang terdapat dalam suatu cerita, teks, tugas-tugas, dan situasi-situasi dalam kehidupan sehari-hari. Masalah masalah yang dipecahkan meliputi semua topik dalam matematika baik dalam bidang geometri, pengukuran, aljabar, bilangan (aritmatika), maupun statistik.

\section{METODE}

Penelitian ini adalah penelitian eksperimen. Jackie Watson sebagaimana yang dikutip oleh Sitorus (2011:111-112) mendefinisikan penelitian eksperimen sebagai berikut: The experimental designs provide the most rigorous test of hypotheses are characterized by the determination of cause and effect relationships between two or more variables (desain penelitian eksperimen melakukan pengujian hipotesis yang ketat dengan menentukan hubungan sebab akibat antara dua atau lebih 
variabel) eksperimen dapat dilakukan di laboratorim, diruang kelas, atau di tempat lain. Menurut Sugiyono (2008:72) penelitian eksperimen dapat diartikan sebagai metode penelitian yang digunakan untuk mencari pengaruh perlakuan tertentu terhadap yang lain dalam kondisi yang terkendalikan.

Menurut Wiersma sebagaimana yang dikutip Emzir (2009:63) mendefinisikan eksperimen sebagai suatu situasi penelitian yang sekurang-kurangnya satu variabel bebas, yang disebut sebagai variabel eksperimental, sengaja dimanipulasi oleh peneliti. Definisi yang lebih jelas diungkapkan oleh Kasiram (2008:210) bahwa eksperimen dapat didefinisikan sebagai suatu model penelitian di mana peneliti memanipulasi suatu stimuli atau kondisi, kemudian mengobservasi pengaruh atau akibat dari perubahan stimuli atau kondisi tersebut pada obyek yang dikenai stimuli atau kondisi tersebut. Dengan demikian penelitian eksperimen adalah penelitian yang memberikan perlakuan (manipulasi) terhadap variable penelitian (variable bebas), kemudian mengamati konsekuensi perlakuan tersebut terhadap obyek penelitian (variable terikat).

Metode penelitian yang digunakan dalam penelitian ini adalah metode eksperimen semu (quasi eksperimen). Pada penelitian ini peneliti menggunakan sekelompok subyek penelitian dari suatu populasi tertentu, kemudian dikelompokan lagi secara random menjadi dua kelompok. Pada kelompok pertama diberlakukan metode pembelajaran inkuiri dan pada kelompok kedua diberlakukan metode pembelajaran diskusi dengan jumlah jam pelajaran yang sama. Selanjutnya pada kedua kelompok kelas itu dilakukan tes hasil belajar yang sama. Hasil tes kedua kelompok di uji secara statistik untuk melihat apakah ada perbedaan yang terjadi karena adanya perlakuan yaitu metode pembelajaran inkuiri dan diskusi. Penelitian ini dilakukan pada siswa kelas VIII SMP Negeri di Kecamatan Palmerah Jakarta Barat yang terdaftar pada tahun pelajaran 2015/2016 yang berjumlah 530 siswa yang terdiri dari SMP Negeri 101 sebanyak 280 siswa dan SMP Negeri 130 Sebanyak 250 siswa. Teknik sampling dalam penelitian ini adalah intact class atau cluster sampling, berdasarkan Factorial Group Design dengan langkah sebagai berikut : (1) mendata jumlah populasi. (2) melakukan teknik pengocokan yaitu nama seluruh kelas yaitu kelas VIIIA sampai dengan kelas VIIIG dimasukan ke dalam tempat tertutup kemudian dilakukan pengocokan, nama kelas yang keluar dijadikan sebagai sampel penelitian. (3) mendata anggota sampel kemudian diberikan instrumen penelitian. Menurut Furchan (1982:189), teknik cluster sampling umumnya dilakukan melalui 2 tahap. Dalam penelitian inipun dilakukan dua tahap, yaitu : Teknik Pertama; pengambilan kelas untuk eksperimen dan kontrol dilakukan dengan teknik simple random sampling ( sampel acak sederhana) mengingat kelas-kelas yang ada (4 kelas) bersifat homogen yang telah dikelompokkan secara proporsional berdasarkan prestasi belajar kelas VIII semester satu. Proses pengambilan sampel kelas dilakukan dengan cara mengundi nama-nama kelas VIII yang ada yaitu VIIIA-VIIID., kelas VIIIA keluar pertama dijadikan kelas eksperimen metode diskusi dan kelas VIIIB keluar kedua sebagai kelas eksperimen metode inkuiri. Teknik Kedua ; pengambilan subjek dilakukan dengan teknik sampling sistematis, yaitu teknik penganbilan sampel berdasarkan urutan dari anggota populasi yang telah diberi nomor urut. Dengan demikian diperoleh 4 kelompok sampel penelitian yaitu 70 siswa 35 siswa dengan metode diskusi, 35 siswa dengan metode inkuiri, dan 70 siswa dari SMPN 130 sebanyak35 siswa dengan metode diskusi, 35 siswa dengan metode inkuiri. Desain penelitian menggunakan desain nonequivalent control group (Tuckman, 1999) digambarkan sebagai berikut: 


\begin{tabular}{|c|c|c|}
\hline & $\begin{array}{c}\text { Kemampuan Komunikasi } \\
\text { Matematika }\end{array}$ & $\begin{array}{c}\text { Kemampuan Pemecahan } \\
\text { Masalah Matematika }\end{array}$ \\
\hline Metode Pembelajaran Diskusi & $\mathrm{YA}_{1} \mathrm{~B}_{1}$ & $\mathrm{YA}_{2} \mathrm{~B}_{1}$ \\
\hline Metode Pembelajaran Inkuiri & $\mathrm{YA}_{1} \mathrm{~B}_{2}$ & $\mathrm{YA}_{2} \mathrm{~B}_{2}$ \\
\hline
\end{tabular}

\section{Gambar 1. Desain Penelitian}

Sumber data mengenai metode pembelajaran diperoleh dari jurnal dan buku-buku yang berkaitan dengan penelitian ini. Data kemampuan matematika dipeoleh darites kemampuan kognitif matematika dengan menggunakan skala Guttman.

Teknik analisis data pada penelitian ini terbagi dalam tiga bagian yaitu uji analisis deskriptif data meliputi ukuran pemusatan data (tendensi sentral) yang terdiri dari modus, median dan mean dan ukuran penyebaran data yang terdiri dari varian simpangan baku, skewness dan kurtosis, uji analisis persyaratan data meliputi uji normalitas data dilakukan untuk mengetahui apakah distribusi sebuah data mengikuti atau mendekati distribusi normal, yakni distribusi data dengan bentuk lonceng (bell shaped), uji general linier model adalah uji prasyarat untuk melihat apakah matriks variankovarian dari dependent variabel sama untuk grup-grup yang ada (independet), uji kesamaan matriks kovarian merupakan pengujian kesamaan varians- kovarian pada kedua variabel terikat secara sendiri-sendiri dan uji analisis hipotesis penelitian yang dilakukan dengan uji MANOVA menggunakan SPSS 22.0. yang meliputi Uji signifikasi multivariat untuk mengetahui adanya perbedaan centroid dua kelompok atau lebih yang dapat dievaluasi dengan berbagai kriteria uji statistik, uji signfikasi univariat dignakan untuk mengetahui variabel mana yang menyebabkan terjadinya perbedaan rata-rata dua kelompok melalui uji univariat $\mathrm{F}$.

\section{HASIL}

Penelitian ini bertujuan untuk mengetahui pengaruh metode pembelajaran diskusi dan inkuiri terhadap kemampuan komunikasi dan pemecahan masalah matematika dan selanjutnya diuji dengan analisis Manova. Berdasarkan hasil perhitungan data deskriptif yang diperoleh kelas yang menggunakan metode pembelajaran diskusi dan kelas yang menggunakan metode pembelajaran inkuri untuk kemampuan komunikasi matematika dan kemampuan pemecahan masalah matematika disajikan sebagai berikut

Tabel 1. Deskriptif Data

\begin{tabular}{|c|c|c|}
\hline Statistis & Komunikasi & Pemecahan_Masalah \\
\hline IValid & 140 & 140 \\
\hline Missing & 0 & 0 \\
\hline Mean & 73,53 & 69,11 \\
\hline Median & 75,00 & 70,00 \\
\hline Mode & $65^{\mathrm{a}}$ & 65 \\
\hline Std. Deviation & 13,522 & 12,860 \\
\hline Variance & 182,855 & 165,391 \\
\hline Minimum & 40 & 35 \\
\hline Maximum & 95 & 90 \\
\hline Sum & 10294 & 9675 \\
\hline
\end{tabular}

Dari tabel 2 di atas diperoleh jumlah sampel varibel komunikasi matematika sebesar 140 dengan nilai rata-rata 73,53; modus 65; median 75; varians 182,855; dan simpangan baku 13,522. secara keseluruahan skor rata-rata $51,53 \%$ metode diskusi dan $48,47 \%$ metode inkuiri. Variabel komunikasi matematika sebesar 140 dengan nilai rata-rata 69,11; modus 65; median 70; varians 
165,391; dan simpangan baku 12,860. Dari data tersebut diperoleh secara keseluruahan 50,88\% metode diskusi dan $49,12 \%$ metode inkuiri.

Pengolahan data dilanjutkan dengan uji analisis persyaratan data yang meliputi uji normalitas data, uji general linier model dan uji kesamaan matriks kovarian. Uji normalitas data dilakukan untuk mengetahui apakah distribusi sebuah data mengikuti atau mendekati distribusi normal, yakni distribusi data dengan bentuk lonceng (bell shaped). Data yang baik adalah data yang mempunyai pola seperti distibusi normal, yakni distribusi data tersebut tidak menceng ke kiri atau ke kanan. Uji normalitas data dilakukan dengan besaran Kolmogorov-Smirnov berikut:

Tabel 2. One-Sample Kolmogorov-Smirnov Test

\begin{tabular}{llrr}
\hline & & Komunikasi & Pemecahan_Masalah \\
\hline N & & 140 & 140 \\
Normal Parameters & Mean & 73,53 & 69,11 \\
& Std. Deviation & 13,522 & 12,860 \\
Most Extreme Differences & Absolute & 0,066 & 0,066 \\
& Positive & 0,056 & 0,054 \\
& Negative & $-0,066$ & $-0,066$ \\
Test Statistic & & 0,066 & 0,066 \\
Asymp. Sig. (2-tailed) & & $0,200^{\mathrm{c}, \mathrm{d}}$ & $0,200^{\mathrm{c}, \mathrm{d}}$ \\
\hline
\end{tabular}

Dari tabel di atas terbaca nilai Kolmogorov-Smirnov $=0,066$ dengan probabiltas 0,200 (Asymp. Sig. (2-tailed)). Karena nilai $\mathrm{p}=0,200>0,05$, maka $\mathrm{H}_{0}$ diterima dan $\mathrm{H}_{1}$ ditolak, yang berarti data variabel komunikasi matematika dan variabel pemecahan masalah matematika berasal dari populasi berdistribusi normal.

Uji general linier model adalah uji prasyarat untuk melihat apakah matriks varian-kovarian dari dependent variabel sama untuk grup-grup yang ada (independet). Uji General Linier Model menggunakan uji Box's Test. Uji Box's Tets merupakan uji normalitas multivariat yaitu pengujian kesamaan varians-kovarians pada kedua variabel terikat secara bersama-sama. Dengan menggunakan angka Box's M test of equality of covariance marices berikut:

Tabel 3. Box's Test of Equality of Covariance Matrices $^{\mathrm{a}}$

\begin{tabular}{lr} 
& \\
\hline Box's M & 1,794 \\
F & 0,589 \\
df1 & 3 \\
df2 & 3427920,000 \\
Sig. & 0,622 \\
\hline
\end{tabular}

Hasil hitungan menunjukkan bahwa (Sig) 0,622 > 0,05 sehingga $\mathrm{H}$ diterima. Artinya kemampuan komunikasi dan pemecahan masalah matematika mempunyai matriks varians-kovarians yang sama pada kelompok metode pembelajaran diskusi dan inkuiri. Sedangkan untuk menguji kehomogenitasan data multivariate atau uji korelasi antar variabel terikat ditunjukkan pada angka melalui Uji Bartlett's Test of Sphericity berikut:

Tabel 5. Bartlett's Test of Sphericity ${ }^{\mathrm{a}}$

\begin{tabular}{ll} 
Likelihood Ratio & 0,000 \\
Approx. Chi-Square & 404,948 \\
Df & 2 \\
Sig. & 0,000 \\
\hline
\end{tabular}

Uji Bartlett ini signifikan sehingga menunjukkan adanya korelasi yang cukup kuar antara variabel terikat yang ada. 
Uji kesamaan matriks kovarian merupakan pengujian kesamaan varians- kovarian pada kedua variabel terikat secara sendiri-sendiri. Pengujian ini merupakan uji univariat $F$ melalui uji varian error yang menggunakan angka-angka Levene's Test of Equality of Error Variance berikut:

Tabel 6. Levene's Test of Equality of Error Variances ${ }^{\text {a }}$

\begin{tabular}{|c|c|c|c|c|}
\hline & $\mathrm{F}$ & df1 & df2 & Sig. \\
\hline Komunikasi & 0,625 & & $\begin{array}{ll}138 \\
\end{array}$ & 0,430 \\
\hline Pemecahan_Masalah & 0,829 & & 1138 & 0,364 \\
\hline
\end{tabular}

Angka signifikasi hasil hitungan variabel terikat komunikasi matematika menunjukkan 0,430 lebih besar dari kriteria 0,05 , sedangkan angka untuk variabel terikat pemecahan masalah matematika juga lebih besar dari 0,05 . Dengan demikian $\mathrm{H}_{0}$ diterima. Artinya variabel terikat kemampuan komunikasi dan pemecahan masalah mateamtika mempunyai matriks varians-kovarians yang sama pada kelompok variabel bebas metode pemebelajaran diskusi dan inkuiri.

Pengujian sendiri-sendiri menunjukkan adanya kesamaan varians-kovarians. Pengujian bersama-sama juga menunjukka adanya kesamaan varians-kovarians. Karena asumsi kesamaan varians-kovarians terpenuhi dari kedua persayaratan tersebut, maka proses analisis MANOVA dapat dilanjutkan. Setelah pengujian persyaratan analisis terpenuhi, selanjutnya dilakukan uji signifikasi multivariat tes.

Tabel 7. Multivariate Tests ${ }^{\mathrm{a}}$

\begin{tabular}{lllllllll}
\hline & \multicolumn{1}{c}{ Effect } & Value & $\mathrm{F}$ & $\begin{array}{l}\text { Hypothesis } \\
\text { df }\end{array}$ & Error df & Sig. & $\begin{array}{c}\text { Partial Eta } \\
\text { Squared }\end{array}$ \\
\hline Intercept & Pillai's Trace & 0,968 & $2099,861^{\mathrm{b}}$ & 2,000 & 137,000 & 0,000 & 0,968 \\
& Wilks' Lambda & 0,032 & $2099,861^{\mathrm{b}}$ & 2,000 & 137,000 & 0,000 & 0,968 \\
& Hotelling's Trace & 30,655 & $2099,861^{\mathrm{b}}$ & 2,000 & 137,000 & 0,000 & 0,968 \\
& Roy's Largest & 30,655 & $2099,861^{\mathrm{b}}$ & 2,000 & 137,000 & 0,000 & 0,968 \\
& Root & & & & & & & \\
Metode & Pillai's Trace & 0,109 & $8,359^{\mathrm{b}}$ & 2,000 & 137,000 & 0,000 & 0,109 \\
& Wilks' Lambda & 0,891 & $8,359^{\mathrm{b}}$ & 2,000 & 137,000 & 0,000 & 0,109 \\
& Hotelling's Trace & 0,122 & $8,359^{\mathrm{b}}$ & 2,000 & 137,000 & 0,000 & 0,109 \\
& Roy's Largest & 0,122 & $8,359^{\mathrm{b}}$ & 2,000 & 137,000 & 0,000 & 0,109 \\
\hline
\end{tabular}

Jika dilihat pada baris di amna variabel bebas metode, angka-angka signifikasi hasil pengujian yang berdasarkan pada Pillai's Trace, Wilks' Lambda, Hotelling's Trace, Roy's Largest Root

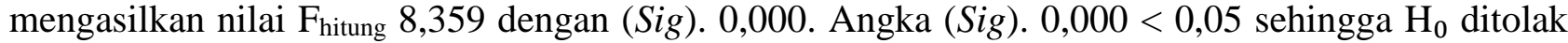
dan $\mathrm{H}_{1}$ diterima, atau variabel komunikasi dan pemecahan masalah matematika menunjukkan perbedaan pada metode pembelajaran yang digunakan. Artinya terdapat pengaruh yang signifikan metode pembelajaran terhadap kemampuan komunikasi dan pemecahan masalah matematika siswa secara multivariat. Untuk mengetahui pengaruh masing-masing variabel secara sendiri-sendiri menggunakan angka-angka uji pengaruh antar subjek dengan uji univariat test. 
Tabel 8. Tests of Between-Subjects Effects

\begin{tabular}{|c|c|c|c|c|c|c|c|}
\hline Source & Dependent Variable & $\begin{array}{l}\text { Type III } \\
\text { Sum of } \\
\text { Squares }\end{array}$ & $f$ & Mean Square & $\mathrm{F}$ & Sig. & $\begin{array}{l}\text { Partial } \\
\text { Eta } \\
\text { Squared }\end{array}$ \\
\hline Corrected & Komunikasi & $713,257^{a}$ & & 713,257 & 3,984 & 0,048 & 0,028 \\
\hline Model & Pemecahan_Masalah & $208,864^{b}$ & & 208,864 & 1,265 & 0,263 & 0,009 \\
\hline \multirow[t]{2}{*}{ Intercept } & Komunikasi & 756903,114 & & 756903,114 & 4228,230 & 0,000 & 0,968 \\
\hline & Pemecahan_Masalah & 668611,607 & & 668611,607 & 4050,319 & 0,000 & 0,967 \\
\hline \multirow[t]{2}{*}{ Metode } & Komunikasi $^{-}$ & 713,257 & & 713,257 & 3,984 & 0,048 & 0,028 \\
\hline & Pemecahan_Masalah & 208,864 & & 208,864 & 1,265 & 0,263 & 0,009 \\
\hline \multirow[t]{2}{*}{ Error } & Komunikasi & 24703,629 & 38 & 179,012 & & & \\
\hline & Pemecahan_Masalah & 22780,529 & 38 & 165,076 & & & \\
\hline \multirow[t]{2}{*}{ Total } & Komunikasi $^{-}$ & 782320,000 & 40 & & & & \\
\hline & Pemecahan_Masalah & 691601,000 & 40 & & & & \\
\hline \multirow{2}{*}{$\begin{array}{l}\text { Correcte } \\
\text { d Total }\end{array}$} & Komunikasi & 25416,886 & 39 & & & & \\
\hline & Pemecahan_Masalah & 22989,393 & 39 & & & & \\
\hline
\end{tabular}

Untuk angka signifikasi pada variabel metode menghaislkan nilai $\mathrm{F}_{\text {hitung }}$ 3,984 dengan (Sig) $0,045<0,05$ sehingga $\mathrm{H}_{0}$ ditolak dan $\mathrm{H}_{1}$ diterima, atau variabel komunikasi matematika menunjukkan perbedaan pada penggunaan metode pembelajaran diskusi dan inkuri. Artinya, terdapat perbedaan kemampuan komunikasi matematika antara metode diskusi dan inkuiri. Sedangkan variabel kemampuan pemecahan masalah matematika. Angka signifikasi pada variabel metode mennghasilkan nilai $F_{\text {hitung }}$ 1,265 dengan ( $\mathrm{Sig}$ ) 0,263>0,05 sehingga $\mathrm{H}_{0}$ diterima dan $\mathrm{H}_{1}$ ditolak, atau variabel pemecahan masalah matematika tidak menunjukkan perbedaan pada penggunaan metode pembelajaran diskusi dan inkuri. Artinya, tidak terdapat perbedaan kemampuan pemecahan masalah matematika antara metode diskusi dan inkuiri. Dalam pengujian ini dapat diambil kesimpualan bahwa terdapat perbedaan dalam kemampuan komunikasi matematika antara metode pembelajaran diskusi dan inkuiri, sedangkan kemampuan pemecahan masalah matematika tidak terdapat perbedaan antara penggunaan metode diskusi dan inkuiri. Sedangkan pengaruh dari dari metode pembelajaran dapat di analisis dari nilai rata-rata pada Estimed Marginal Mean.

Tabel 9. Estimated Marginal Mean

\begin{tabular}{|c|c|c|c|c|c|}
\hline \multirow[b]{2}{*}{ Dependent Variable } & \multirow[b]{2}{*}{ Metode } & \multirow[b]{2}{*}{ Mean } & \multirow[b]{2}{*}{ Std. Error } & \multicolumn{2}{|c|}{$\begin{array}{l}95 \% \text { Confidence } \\
\text { Interval }\end{array}$} \\
\hline & & & & Lower Bound & Upper Bound \\
\hline \multirow[t]{2}{*}{ Komunikasi } & Metode Diskusi & 75,786 & 1,599 & 72,62 & 78,94 \\
\hline & Metode Inkuiri & 71,271 & 1,599 & $\begin{array}{r}68,10 \\
9\end{array}$ & $\begin{array}{r}74,43 \\
3\end{array}$ \\
\hline \multirow[t]{2}{*}{ Pemecahan_Masalah } & Metode Diskusi & 70,329 & 1,536 & $\begin{array}{r}67,29 \\
2\end{array}$ & $\begin{array}{r}73,36 \\
5\end{array}$ \\
\hline & Metode Inkuiri & 67,886 & 1,536 & $\begin{array}{r}64,84 \\
9\end{array}$ & $\begin{array}{r}70,92 \\
2\end{array}$ \\
\hline
\end{tabular}




\section{PEMBAHASAN}

Hasil pengujian hipotesis membuktikan bahwa ada perbedaan perolehan kemampuan komunikasi matematika maupun pemecahan masalah matematika antara pebelajar yang belajar dengan metode diskusi dan metode inkuiri. Kedua metode ini pada dasarnya menekankan pada kemampuan maksimal individu utuk terlibat dalam aktivitas, alternatif bagi siswa untuk menemukan fakta, konsep, prinsip dan keterampilan.

Dari hasil uji hipotesis menggunakan uji multivariat MANOVA yang diuji secara bersamaan diketahui hasilnya bahwa terdapat perbedaan antara metode diskusi dan inkuiri terhadap kemampuan komunikasi dan pemecahan masalah matematika. Keduanya menunjukkan angka Sig. 0,00 dengan nilai Fhitung 8,359 (Tabel 8) dimana dalam kaidahnya jika Sig. < 0,05 maka $\mathrm{H}_{0}$ ditolak sehingga dapat dikatakan bahwa terdapat pengaruh metode pembelajaran terhadap kemampuan komunikasi dan pemecahan masalah matematika siswa secara multivariat.

Metode pembelajaran sangat besar pengaruhnya dalam penguasaan kemampaun kognitif seseorang. Kemampuan belajar siswa yang baik diperoleh dari proses belajar yang benar. Proses belajar yang benar adalah proses belajar yang melibatkan siswa itu sendiri. Untuk itu guru harus menggunakan metode pembelajaran yang dapat melibatkan siswa secara aktif dalam kegiatan belajar mengajar. Salah satu yang dapat menunjang hal tersebut adalah metode inkuiri dan diskusi

Dalam pembelajaran matematika berbagai metode dapat digunakan untuk mencapai tujuan pemebelajaran matematika disekolah. Antar metode memiliki kelebihan dan keunggulan dalam pelaksanaannya, namun dalam meningkatkan kemampuan matematika siswa dapat diukur melalui tes uraian untuk mengetahui kompetensi dasar siswa dalam penguasaan matematika atau kemampuan matematika siswa. Baik metode inkuiri dan metode diskusi keduanya merupakan suatu cara dalam menyajikan (menguraikan, memberi contoh dan memberi latihan) untuk mencapai tujuan meningkatkan kemampuan matematika yaitu kemampuan komunikasi matematika dan kemampuan pemecahan masalah yang dilakukan melalui proses menemukan dan interkasi siswa dengan siswa, siswa dengan guru suatu pemecahan masalah/latihan matematika.

Hasil pengujian hipotesis membuktikan bahwa ada perbedaan perolehan kemampuan komunikasi matematika antara pebelajar yang belajar dengan metode diskusi dan metode inkuiri.

Dari hasil uji hipotesis menggunakan uji Tests of Between Subject Effect di dapatkan nilai F hitung untuk kemampuan komunikasi matematika sebesar 3,984 dengan (Sig.) 0,048 < 0,05 yang memenuhi kriteria. Dengan demikian disimpulkan secara individu terdapat perbedaan kemampuan komunikasi matematika yang diajarkan dengan metode diskusi dan metode inkuiri. Efek kedua perbedaan tersebut dapar terlihat pada nilai Partial Eta Squared (PES) sebesar 2,8\% (Tabel 9). sedangkan pada tabel 4.11 terlihat bahwa metode diskusi memperngaruhi kemampuan komunikasi matematika sebesar 75,786 lebih besar dari metode inkuiri sebesar 71,271.

Kemampuan komunikasi matematika adalah kemampuan siswa dalam menyampaikan ide/gagasan matematika baik melalui lisan maupun tulisan dengan simbol-simbol, grafik atau diagram untuk menjelaskan masalah dari informasi yang diperoleh. Metode pembelajaran yang mengarahkan pada kemampuan komunikasi matematika merupakan proses berpikir kritis dan proses mental untuk mencari dan menemukan jawaban sendiri dalam belajar dapat dilakukan secara individu ataupun kelompok melalui identifikasi, penyelidikan dan penemuan, analisis dan penguatan terhadap hal-hal baru yang ditemukan. Proses tersebut dapat dilakukan dengan keterampilan dalam menjelaskan melalui membuat laporan hasil penyelesaian latihan/tugas-tugas terstruktur matematika. Keterampilan menjelaskan secara sederhana dalam pengembangan pembelajaran matematika terdiri dari dua langkah, pertama yaitu perencanaan yang terdiri dari isi penjelasan dan analisis persoalan yang akan di bahas, contoh dan latihan dan yang kedua yaitu 
pelaksanaan. Pada pokok bahasan operasi aljabar kemampuan komunikasi matematika siswa ditntut untuk melakukan penyelesaian secara runtut dalam berbagai tahap atau langkah. Dalam proses pembelajaran dengan menggunakan kedua metode pembelajaran anggota kelompok saling berinteraksi sehingga memengaruhi kelompok secara keseluruhan

Hasil pengujian hipotesis membuktikan bahwa tidak terdapat perbedaan perolehan kemampuan pemecahan masalah matematika antara pebelajar yang belajar dengan metode diskusi dan metode inkuiri.

Dari hasil uji hipotesis menggunakan uji Tests of Between Subject Effect di dapatkan nilai F hitung untuk kemampuan pemecahan masalah matematika sebesar 1,265 dengan (Sig.) 0,263>0,05 yang tidak memenuhi kriteria. Dengan demikian disimpulkan secara individu tidak terdapat perbedaan kemampuan komunikasi matematika yang diajarkan dengan metode diskusi dan metode inkuiri. Efek kedua perbedaan tersebut dapar terlihat pada nilai Partial Eta Squared(PES) sebesar 0,9\% (Tabel 9)

Pemecahan masalah merupakan kemampuan dasar yang harus dikuasai oleh siswa. Bahkan tercermin dalam konsep kurikulum berbasis kompetensi. Tuntutan akan kemampuan pemecahan masalah dipertegas secara eksplisit dalam kurikulum tersebut yaitu, sebagai kompetensi dasar yang harus dikembangkan dan di integrasikan pada sejumlah materi yang sesuai. Pentingnya kemampuan penyelesaian masalah oleh siswa dalam matematika meliputi beberapa hal; 1) Kemampuan menyelesaikan masalah merupakan tujuan umum pengajaran matematika; 2) Penyelesaian masalah yang meliputi metode, prosedur dan strategi merupakan proses inti dan utama dalam kurikulum matematika; 3) Penyelesaian masalah merupakan kemampuan dasar dalam belajar matematika. Pandangan bahwa kemampuan menyelesaikan masalah merupakan tujuan umum pengajaran matematika, mengandung pengertian bahwa matematika dapat membantu dalam memecahkan persoalan baik dalam pelajaran lain maupun dalam kehidupan sehari-hari. Oleh karenanya kemampuan pemecahan masalah ini menjadi tujuan umum pembelajaran matematika.

Pandangan pemecahan masalah sebagai proses inti dan utama dalam kurikulum matematika, berarti pembelajaran pemecahan masalah lebih mengutamakan proses dan strategi yang dilakukan siswa dalam menyelesaikannya dari pada hanya sekedar hasil sehingga keterampilan prosesdan strategi dalam memecahkan masalah tersebut menjadi kemampuan dasar dalam belajar matematika. Walaupun kemampuan pemecahan masalah merupakan kemampuan yang tidak mudah dicapai, akan tetapi oleh karena kepentingan dan kegunaannya maka kemampuan pemecahan masalah ini hendaknya diajarkan kepada siswa pada semua tingkatan.

Hasil penelitian ini menunjukkan bahwa penggunaan metode pembelajaran diskusi lebih baik dan lebih unggul dalam meningkatkan kemampuan komunikasi matematika dibandingkan dengan penggunaan metode inkuiri. Hal ini terjadi disebabkan karena dalam pembelajaran di kelas dimana interaksi siswa berkemampuan tinggi memengaruhi siswa lainnya secara keseluruhan. Interkasi diantara siswa melahirkan strukturasi kelompok sebagai hasil dari interkasi anggota-anggotanya yaitu aturan yang menunjukkan apa yang harus dan tidak boleh dilakukan dan sumber daya yaitu berkaitan dengan segala sesuatu yang dapat digunakan untuk memengaruhi atau mengendalikan tindakan kelompok atau anggota-anggota kelompok dalam pembelajaran matematika. 


\section{SIMPULAN}

Hasil penelitian menunjukkan terdapat pengaruh yang signifikan metode pembelajaran terhadap kemampuan komunikasi dan pemecahan masalah matematika secara multivariat yang berarti kedua metode yang digunakan secara multivariat memberikan pengaruh yang signifikan terhadap kemampuan komunikasi dan pemecahan masalah matematika siswa sebesar 10,9\% melalui Partial Eta Squared dan terdapat pengaruh yang signifikan metode pembelajaran terhadap kemampuan komunikasi matematika secara univariat yang berarti kedua metode pembelajaran metode diskusi dan metode inkuiri secara individu memberikan pengaruh yang signifikan terhadap kemampuan komunikasi matematika serta terdapat pengaruh yang tidak signifikan metode pembelajaran terhadap kemampuan pemecahan masalah matematika secara univariat, dimana kedua metode pembelajaran metode diskusi dan metode inkuiri memberikan pengaruh yang tidak signifikan terhadap kemampuan pemecahan masalah matematika. Hal ini berarti bahwa kemampuan pemecahan masalah matematika tidak hanya bergantung pada metode pembelajaran yang digunakan, hal tersebut terlihat secara deterministik sebesar $0,9 \%$ dan $91,1 \%$ dipengaruhi oleh faktor lain.

Untuk mengembangkan penelitian ini lebih lanjut, maka diperlukan variabel lain yang dapat dikontrol untuk mempengaruhi metode pembelajan diskusi dan inkuiri terhadap kemampuan pemecahan masalah matematika. Variabel lain yang dapat dikontrol/dikendalikan dalam metode pembelajaran adalah budaya atau lingkungan belajar sekolah, perilaku siswa yang terintegrasi dalam metode pembelajaran inkuiri dan diskusi guna meningkatkan kemampuan matematika itu sendiri sehingga metode pembelajaran dapat memberikan pengaruh terhadap peningkatan kemampuan pemecahan masalah matematika siswa disekolah.

\section{DAFTAR RUJUKAN}

Adi W. G.(2007). Genius Learning Strategy: Petunjuk Praktis untuk Menerapkan Accelarated Learning, Jakarta: PT. Gramedia Pustaka Utama.

Ansari, I.B. (2009). Komunikasi Matematik Konsep dan Aplikasi. Banda Aceh: Yayasan Pena.

Atmaha, U. (2018). Media Pembelajaran. http://ulfiaatm.blogspot.com / 2013/06/ metode-diskusi.html. Diakses 03/05/2018 9:34:01

Badan Standar Nasional Pendidikan (BSNP). (2006). Model Penilaian Kelas. Jakarta: Depdiknas.

Bennett, A.B. (2004). Mathematic for Elementary Teachers A Conceptual Approach. WI: New York: Aleks Corporation.

Danoebroto, S.W., (2011). Faktor-Faktor Yang Berpengaruh Terhadap Kemampuan Siswa Memecahkan Masalah Matematika. http://p4tkmatematika.org/file/Karya\%20WI14\%20s.d\%2016\%200kt\%202011/Faktor\%20dalam\% 20Problem\%20Solving.pdf. Diakses 24 Maret 2013

Darto. (2008). "Meningkatkan Kemampuan Komunikasi dan Pemecahan Masalah Matematis Siswa Melalui Pendekatan Realistic Mathematics Education di SMP Negeri 3 Pangkalan Kuras".Thesis. UNP.

Depdikbud. (2008). Kamus Besar Bahasa Indonesia. Jakarta: Balai Pustaka

Dharma, S. (2008). Strategi Pembelajaran dan Pemilihannya. Jakarta: Direktur Tenaga Kependidikan. Departemen Pendidikan Nasional.

Emzir. (2009). Metodologi Penelitian Pendidikan Kuantitatif dan Kualitatif, Jakarta: Raja Grafindo Persada

Fitrianik. (2010). "Keefektifan Pembelajaran Kooperatif Tipe CIRC Berbantuan Kartu SoalTerhadap Kemampuan Pemecahan Masalah Dalam Menyelesaikan Soal Cerita Matematika Pada SMP Negeri 2 Ulujami”, Skripsi (Semarang: Program Sarjana UNNES.2010 
Goetz, J. (2004). Top Ten Thoughts about Communication in Mathematics.http://www.kent.k12.wa.us/KSD/15/Communication_in_math.htm. (diakses 20 Oktober 2011)

Herdian. (2011). Kemampuan Komunikasi Matematika, (online), (http://herdy07_wordpress.com). diakses 22 oktober 2011

Hudojo, H.(1990). Strategi Mengajar Belajar Matematika. Malang: IKIP Malang. 1990

Jihad, A. (2008). Pengembangan Kurikulum Matematika Tinjauan Teoritis dan Historis, (Bandung: Multi Pressindo.

Kasiram, M., (2008). Metodologi Penelitian Refleksi Pengembangan Pemahaman dan Penguasaan Metodologi Penelitian. Malang: UIN-Malang Press

Kunandar. 2008. Langkah Mudah Penalitian Tindakan Kelas Sebagai Pengembangan Profesi Guru. Jakarta: Raja Grafindo Persada.

LACOE (Los Angeles County Office of Education). Communication. http://teams.lacoe.edu. 2004.

Latifah, E. (2013). Perbedaan Diskusi dan Debat. http://euislatifah.blogspot.com/ 2013/11/perbedaandiskusi-dan-debat.html. Diakses 03/05/2018 9:34:01

Naim, N. (2011). .Dasar - Dasar Komunikasi Pendidikan. Yogyakarta : AR-RUZMEDIA

Nasution, S., (2008). Berbagai Pendekatan dalam Proses Belajar Mengajar. Jakarta: Bumi Aksara.

NCTM. (2000). Principles and Standards for School Mathematics. Reston: NCTM Peraturan Menteri Nomor 23 Tahun 2006 Tentang Standar Kompetensi Lulusan.

.(2003). Program Standards. Program for Initial Preparation ofMathematics Teacher. Standar for Scondary Mathematics Teachers.Tersediadi http://www.math.uri.edu/ eaton/NCATENCTM.pdf. Diaksestanggal 09 April 2012.

Ramadhina, D. (2007). Pengaruh kemampuan bernalar dan kemampuan Komunikasi Matematika Terhadap Kemampuan Menyelesaikan Soal Cerita Melalui Model Pembelajaran Pemecahan Masalah.http://digilib.umnes.ac.id (diakses 20 Oktober 2011)

Risnawati, (2008). Strategi Pembelajaran Matematika. Pekanbaru: Suska Pers

Sofan, A., dkk. (2010). Proses Pembelajaran Kreatif dan Inofatif dalam Kelas, Jakarta: Prestasi Pustaka.

Sahidin, L., (2011). Membangun komunikasi matematika siswa. (online) Blog Latif Sahidin, diakses 20 Oktober 2011

Shadiq, F., (2004). Pemecahan Masalah, Penalaran dan Komunikasi. Makalah disampaikan Pada Diklat Instruktur/Pengembang Matematika SMA Jenjang Dasar di PPPG Matematika. Yogyakarta.

Sitorus, M., (2011). Metodologi Penelitian Pendidikan Islam, Medan: IAIN Press

Slameto. (1991). Proses Belajar Mengajar Dalam Sistem Kredit Semester (SKS), Jakarta: BumiAksara.

Sudjana, N., (2008). Penilaian Proses Hasil Belajar Mengajar. Bandung: Remaja Rosdakrya (2009). Penilaian Hasil Belajar Mengajar. Bandung: PT Remaja Rosdakarya

Sulastri, (2008).“Penerapan Model Pembelajaran Kooperatif Tipe Think-Pair-Share (TPS) dan Numbered Heads Together (NHT) melalui Pemanfaatan LKS terhadap Kemampuan Komunikasi Matematik pada Siswa SMP”, Skripsi. Semarang: Program sarjana UNNES.

Suriasumantri, J.S., (2007). Filsafat Ilmu Sebuah Pengantar Populer. Jakarta: Pustaka Sinar Harapan

Sugiyono, (2008). Metode Penelitian Kuantitatif, Kualitatif dan R\&D, Bandung: Alfabeta.

Syaban, M. (2011). Menumbuhkembangkan daya Matematis Siswa. Pendidikan dan Budaya, (online), (http://educare,e-fkipunla.net, diakses ( 20 Oktober 2011).

Takahashi, A. (2006). Communication as A Process to for Students to Learn Mathematical.http://www.criced.tsukuba.ac.jp/math/apec/apec2008/papers/PDF/14.Akihiko_Taka hashi_USA.pdf. (diakses 20 Oktober 2011)

Wardani, S., (2005). "Prinsip Penilaian Pembelajaran Matematika SMP”, dalam TIM PPPG Matematika, Materi Pembinaan Matematika SMP di Daerah. Yogyakarta: Depdiknas.

Wena, M., (2009). Strategi Pembelajaran Inovatif Kontemporer. Jakarta, 2009.

Zakaria, E. (2007). Trend Pengajaran dan Pembelajaran Matematika, Kuala Lumpur: Publications \& Distributor SDN BHD. 